\title{
SHORTER CONTRIBUTIONS TO GENERAL GEOLOGY, 1919.
}

\author{
AN EOCENE FLORA FROM TRANS-PECOS TEXAS.
}

\author{
By Edward Wilber Berry.
}

INTRODUCTION.

During the fall of 1916 I received a small collection of fossil plants which had been obtained during a geologic reconnaissance of the trans-Pecos region of Texas, by Charles Lawrence Baker. A preliminary report was sent to Mr. Baker in November of that year and was quoted in his discussion of the geology of that region. ${ }^{1}$ I have since made a careful study of the collection, and although it contains only a few species the occurrence of fossil plants in this region is worthy of more definite and detailed record, especially as these plants enabled me to assign a definite age to the beginning of the igneous activity of the region and to establish correlations between the floras of the Mississippi embayment and the Rocky Mountain region.

A general account of the geology is contained in a recent paper by Baker and Bowman, already cited. The fossil plants, which are described in the following pages, were found in the basal tuffs of the Barilla Mountains between 10 and 15 miles south of Toyahvale and not far east of the main road from Toyah to Fort Davis. These tuffs are rhyolitic and not andesitic like those of the Denver Basin, which contain what appears to have been a contemporaneous flora, and they overlie unconformably beds which are of Pierre (Cretaceous) age, according to Baker and Bowman's determination of the geology.

One is tempted to assign all of what might be called the Laramide epoch of igneous activity along the Rocky Mountain front to the early Tertiary. There certainly appears to

1 Baker, C. L., and Bowman, W. F., Geologic exploration of the southeastern front range of trans-Pecos Texas: Texas Univ. Bull. 1753, pp. 123-124, 1917. have been synchroneity of inception of volcanism in the Denver, Raton Mesa, and Barilla Mountain regions, although farther north, in Montana, this activity appears to have commenced at an earlier date. Rhyolitic lavas overlie the coal-bearing San Carlos formation, which is of Upper Cretaceous age, and are present also in the Sierra Vieja of Texas. ${ }^{2}$ The basalts and phonolites of Uvalde and Travis counties intrude the Taylor marl (Upper Cretaceous) and are commonly considered to be of Tertiary age. Ash beds are also known to occur in the Texas Coastal Plain in late Eocene rocks, while on the other hand Udden reports volcanic tuffs in the Chisos country which are said to be interbedded in rocks of Navarro (Upper Cretaceous) age. It appears evident that no reliance can be placed upon the volcanism as furnishing even an approximate datum plane for correlation, although it seems to be established that the Cordilleran orogenesis of the Tertiary was accompanied by volcanic activity on a grand scale.

ENVIRONMENTAL CONDITIONS INDICATED BY THE FLORA.

The flora here described was found about 340 miles west of the most westerly known outcrop containing fossil plants of Wilcox (lower Eocene) age, which is on Calaveras Creek in Wilson County, Tex.; 355 miles west of the most westerly known outcrop containing supposed Midway (Eocene) plants; 500 miles almost due south of the Raton Mesa country, in southeastern Colorado and northeastern New Mexico, which yields the flora of the Raton formation; and 670 miles south of the

2 Vaughan, T. W., Reconnaissance in the Rio Grande coal fields of Texas: U. S. Geol. Survey Bull. 164, pp. 76-83, 1900. 
Denver Basin, which yields the flora of the terminable, so that too much reliance can not Denver formation.

be placed on the temperature and moisture

The tuffs containing this flora are thus requirements of the existing cabbage palmetto. about halfway between the Gulf Coastal Plain province and the rocks containing the southernmost known early Eocene floras along the present Rocky Mountain front. The flora is therefore of great interest for the information which its study affords regarding former climatic conditions in the region of its occurrence. Unfortunately the number of plants described is entirely too small to furnish precise paleoecologic data. At the same time certain leading features stand out very clearly despite the small number of forms represented. Baker and Bowman report an abundance of silicified logs from the tuffs, some as large as 3 feet in diameter. I have specimens of at least two species of petrified wood, which have not yet been sectioned, but one is of an open-pored, dicotyledonous type and indicates climatic conditions quite different from the semiaridity that now prevails in trans-Pecos Texas.

All the identified forms from these tuffs, except the two new species, are common to the floras of either the Midway (?) or Wilcox of the Coastal Plain or to the floras of the Raton or Denver of the Rocky Mountain province. This in itself is conclusive proof that the general climatic conditions in trans-Pecos Texas at that time were very similar to those of the coastal region to the southeast and of the interior region to the northwest. It also furnishes collateral evidence of the lack of a lofty mountain axis traversing the western interior at that time and shows that an interchange of life forms between the southeastern coastal region and the interior region was readily possible- a conclusion sustained by the considerable number of species known to be common to the early Tertiary floras of the Gulf Coastal Plain and those of the West (Denver, Raton, Fort Union, etc.).

The presence of two individually abundant species of palms in the flora from the Barilla Mountains, one a fan palm and the other a pinnately veined palm of the feather palm type, may be noted. The fan palm (Sabalites) appears to be most like the existing species of Sabal, the arborescent forms of which are now essentially coastal types that extend as far northward as latitude $35^{\circ}$. The botanic affinity of the fossil is, however, not certainly de- New Zealand. In the United States the varigroup of fossil forms typified in the existing flora by the genus Geonoma. Geonoma is now widely distributed in tropical and subtropical America and finds its maximum representation in the Amazon River basin. The fossil forms that have hitherto been referred to Geonomites are found in assemblages which indicate a range from humid warm temperate conditions (for example, those of the Denver flora) to what appear to have been typically tropical conditions (for example, those of the flora of the Italian lower Oligocene). Thus the presence of a small Geonomites in the Barilla Mountain region argues for an abundant supply of moisture, like that required by the Sabalites, and for a somewhat warmer temperature. The true measures for both temperature and moisture of this region in Eocene time may properly be considered as falling somewhere between the extremes indicated for these two types of palms.

The Juglans, from its distribution during the Eocene as well as its general geologic history and the existing ranges of its modern representatives, may be taken to indicate warm temperate conditions of abundant but not excessive precipitation. The Asimina and Oreodaphne fit in nicely with such assumed conditions, for while both genera have tropical representatives, others of their species extend long distances into the Temperate Zone, as for example Asimina triloba Dunal, our common American papaw (not to be confused with the papaws of tropical climes, which belong to a different family of plants), which is not uncommon in the Middle Atlantic States and is precariously hardy as far north as Massachusetts. The Ilex is the only known member of this flora that might have flourished in an environment of scanty rainfall, for it appears to have been an evergreen form or at least of a coriaceous, evaporation-resisting type. The different species of Ilex, however, show a wide range in their climatic requirements, and among the large number of existing species (more than 200) some have succeeded in occupying all the tropical and temperate regions of the globe except western North America, Australia, and 
ous species of holly are confined to the southeastern part of the country, and several reach their western limits in east or central Texas. The occurrence in the Barilla Mountains is therefore slightly beyond the normal western limit of range of the existing North American hollies, but as several species occur in the Tertiary floras of the Rocky Mountain province this occurrence is without any special significance.

Summarizing the indications afforded by the different species of plants found as fossils in the basal tuffs of the Barilla Mountains we may legitimately conclude that they point to warm temperate climatic conditions with abundant precipitation and a plentiful supply of ground water. The actual temperatures can not be estimated, but hard winters may be regarded as very improbable, and there is nothing to indicate that mild winters such as occur at the present time in the Coastal Plain portions of the Carolinas and Georgia would have been prohibitive to the existence of the plants found in these tuffs. We may therefore picture the climatic conditions of trans-Pecos Texas during the period in which these plants flourished as corresponding to those found at the present time in the Coastal Plain portion of South Carolina.

\section{AGE OF THE FLORA.}

Although the determined forms are but six in number and two of the six are new to science, it is possible to reach somewhat definite conclusions regarding the age of the flora. In a subsequent paragraph the question of the exact horizon in the Eocene to which this flora should be referred is considered, but it may be noted here that the four species which occur outside of the Barilla Mountains are all found in the early Eocene of the Rocky Mountain province or in the corresponding beds of the Atlantic Coastal Plain, and on the other hand none of these forms are certainly found in the Upper Cretaceous of these or any other areas. It is true that Asimina eocenica has been recorded from the Montana group, but as I pointed out in discussing the presence of this species in the Midway (?) flora of Texas, ${ }^{1}$ the Upper Cretaceous material referred to this form is not identical with it, nor is it even referable to the genus Asimina, which is not yet known from the Upper Cretaceous.

\footnotetext{
${ }^{1}$ Berry, E. W., U. S. Geol. Survey Prof. Paper 91, p. 14, 1916.
}

Similarly palm remains identified as those of Sabalites grayanus have been reported from the Upper Cretaceous of the Western States. Sabalites is, however, a form genus for fossil fan palms whose generic affinity is not certainly known, and it is thus without significance in the present connection, even if there were any adequate ground for identifying the western material as Sabalites grayanus, which there is not.

Another criterion in evaluating the present flora is furnished by the absence from it of certain elements. Although negative evidence is rightly considered of less value than positive evidence, it remains true that the types of plants that are most successful in resisting decay and those that almost invariably survive maceration and thus become fossilized in a recognizable form when they are at all common in any region are the gymnosperms. The Mesozoic has frequently been termed the age of gmynosperms or the age of conifers, from the preponderance of the remains of those plants in the floras of that era, and a considerable proportion of the older Mesozoic types survived throughout Upper Cretaceous time. These include the important genera Sequoia, Geinitzia, Araucaria, Widdringtonites, Brachyphyllum, Baiera, Czekanowskia, Moriconia, Androvettia, Thuites, and numerous others. Fragments of leafy twigs or cone scales are present in many coarse deposits in which all the other vegetable material has been reduced to unrecognizable débris. There are no traces of gymnosperms in the plant remains found in the basal tuffs of the Barilla Mountains, and from this negative evidence, which must be regarded as of considerable importance, I conclude that the age of these tuffs must be post-Cretaceous.

The genus Geonomites is distinctly a Tertiary type, for here again, notwithstanding the fact that species of Geonomites have been reported from the Upper Cretaceous of southwestern Texas, I have all the collected material and can state positively that Geonomites has never been found in the Upper Cretaceous deposits, the specimens that have been identified as representing this genus being obviously those of fan palms and not feather palms. The other three genera represented in the flora from the tuffs of the Barilla Mountains-Ilex, Juglans, and Oreodaphne-are all genera with a known Upper Cretaceous ancestry and are commonly found among Upper Cretaceous collections of plants. 
Juglans offers but slight evidence either for or against the Cretaceous or Eocene age of the deposits, but the species of both Ilex and Oreodaphne are decisively more modern in their affinities than any Cretaceous forms known to me. Moreover, the present small flora lacks altogether the commoner Upper Cretaceous dicotyledons, some of which would almost certainly be present had the deposits been accumulated during the Upper Cretaceous epoch. I conclude from these facts that this flora is of early Eocene rather than of late Upper Cretaceous age.

The question of the exact horizon in the known Eocene with which these tuffs should be correlated is, in the absence of more extensive collections, more or less debatable. It will be seen from the accompanying table of distribution that two or possibly three of the species, namely, Sabalites grayanus, Juglans rugosa, and Asimina eocenica (?), are present in the flora of the Raton formation of the southern Rocky Mountain region and that these same three species are also present in the Denver formation of Colorado. Asimina eocenica occurs in the Midway (?) formation of the Texas Coastal Plain, and both Sabalites grayanus and Oreodaphne pseudoguianensis are common in the deposits of the Wilcox group in the Mississippi embayment. The two lastnamed species are among the commoner species in the Wilcox flora, and the Sabalites is found at many localities and horizons in beds of Wiloox age. Both occur along the western shores of the Wilcox Mississippi embayment, and Sabalites has been found in beds of this age in western Texas. It is well recognized by most paleontologists that the commoner and more widely distributed forms of a flora or a fauna are less useful in oritical comparisons than the less common forms - that is to say, the less common forms have a more precise value, as the commoner forms generally range through a longer period of time.

This fact and the further fact that only these two of the nearly 350 known Wilcox species have been found in the tuffs of the Barilla Mountains, whereas one of a known Midway (?) flora of but 10 species occurs in the still smaller flora from the Barilla Mountains, indicate very strongly that the latter flora should be correlated with the Midway (?) flora. All the species of both floras are dicotyledons. The fact that half of the six known species from the tuffs are found also in the Raton and Denver floras strongly reinforces this conclusion, for in a detailed comparison of these floras with that of the Wilcox, I have given the evidence for considering them as approximately synchronous and older than the Wilcox flora. ${ }^{1}$

I conclude, therefore, that the basal tuffs in the Barilla Mountains are post-Cretaceous and pre-Wilcox in age and that they and the volcanic activity which they represent were probably contemporaneous with the floras and similar volcanic activity reflected in the Raton and Denver formations and elsewhere in the Rocky Mountain region.

Range of fossil plants found in the tuffs of the Barilla Mountains, Tex.

\begin{tabular}{|c|c|c|c|c|}
\hline & 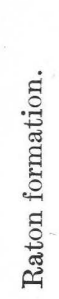 & 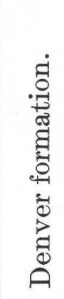 & 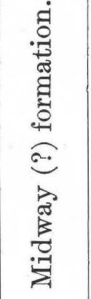 & 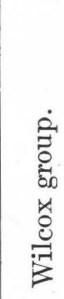 \\
\hline 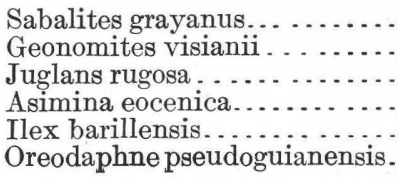 & $\begin{array}{c}X \\
X \\
X \\
? \\
\cdots\end{array}$ & $\begin{array}{l}X \\
X \\
X \\
X \\
\cdots\end{array}$ & $\begin{array}{c}\cdots \cdots \\
\cdots \cdots \\
\cdots \\
\cdots \\
\cdots \cdots \\
\cdots \cdots\end{array}$ & $\begin{array}{r} \\
X \\
\cdots \\
\cdots \\
\cdots \\
X\end{array}$ \\
\hline
\end{tabular}

SYSTEMATIC DESCRIPTIONS.

Phylum ANGIOSPERMOPHYTA.

Class MONOCOTYLEDONAE.

Order ARECALES.

Family ARECACEAE.

Genus SABALITES Saporta.

Sabalites grayanus (Lesquereux) Berry (?).

Plate I; Plate III, figure 5.

Sabal grayana Lesquereux, Am. Philos. Soc. Trans., vol. 13, p. 412, pl. 14, figs. 4-6, 1869. (Not Lesquereux, 1871, 1874, 1876, 1878, or Knowlton, 1900.)

Sabalites grayanus (Lesquereux) Berry, U. S. Geol. Survey Prof. Paper 91, p.177, pl.12, figs. 1-3; pl. 14, fig. 1, 1916.

Knowlton, U. S. Geol. Survey Prof. Paper 101, p. 288, 1918.

Flabellaria eocenica Lesquereux, The Tertiary flora, p. 111, pl. 13, figs. 1-3, 1878.

1 Berry, E. W., U. S. Geol. Survey Prof. Paper 91, p. 148, 1916, 


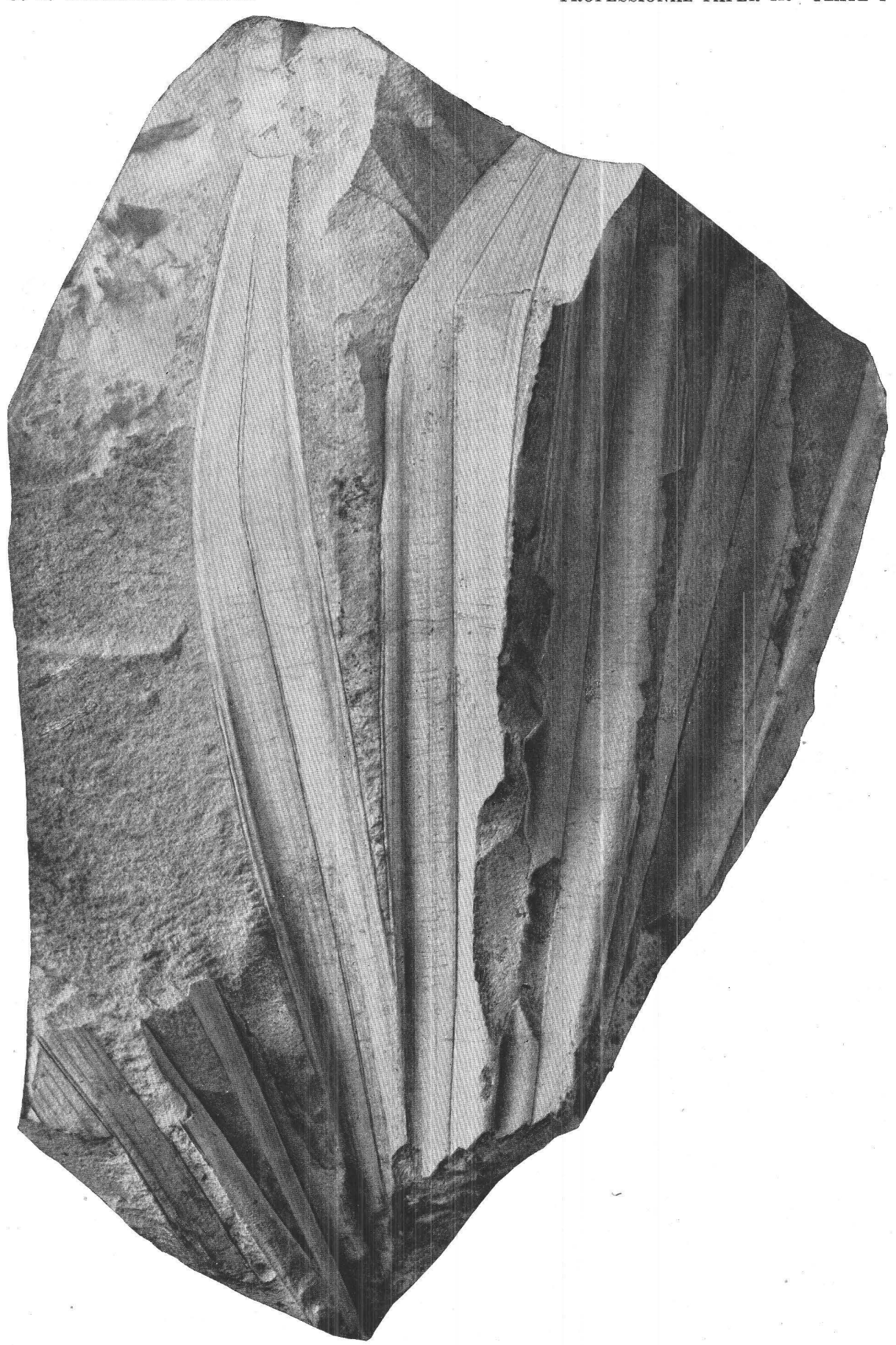

FOSSIL PLANT FROM THE BASAL TUFFS OF THE BARILla MOUNTAINS, TEX.

Sabalites grayanus (Lesquereux) Berry (?). 


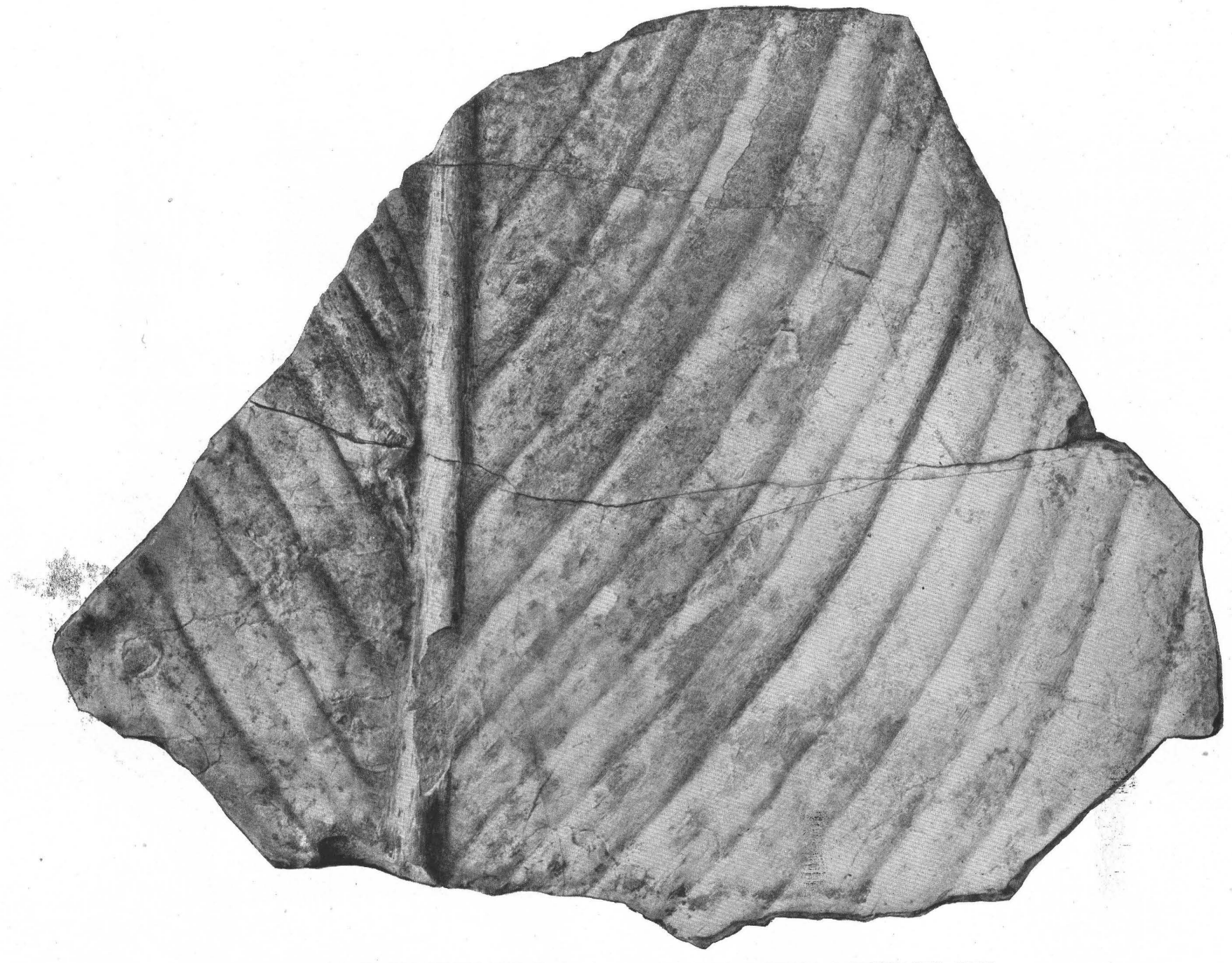

FOSSIL PLANT FROM THE BASAL TUFFS OF THE BARILLA MOUNTAINS, TEX. 
U. S. GEOLOGICAL SURVEY

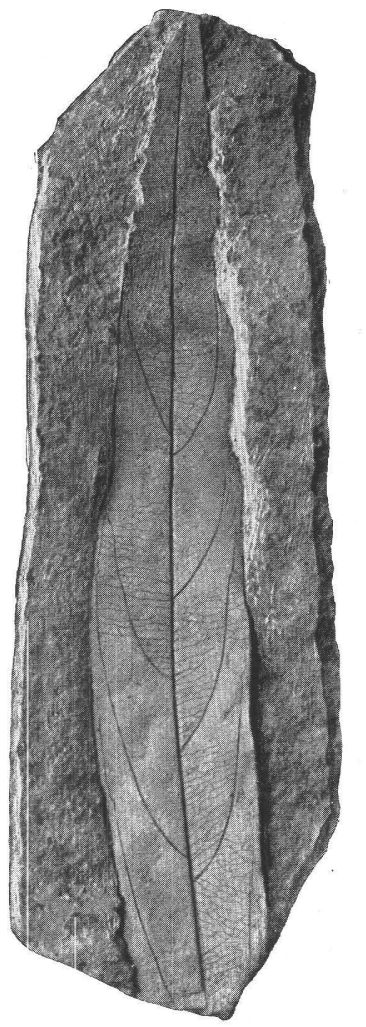

1
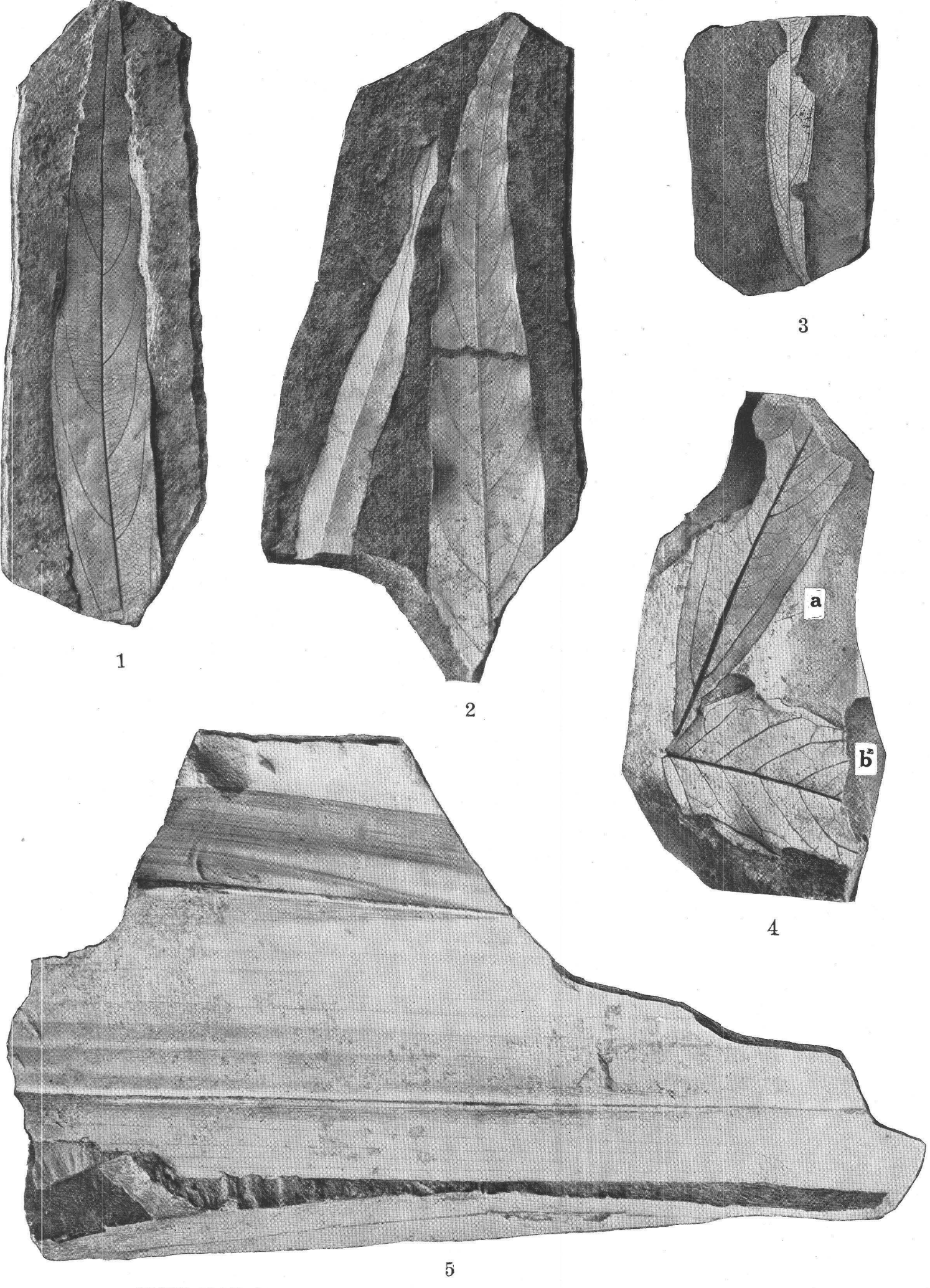

FOSSIL PLANTS FROM THE BASAL TUFFS OF THE BARILLA MOUNTAINS, TEX.

1-3, 4a, Oreodaphne pseudoguianensis Berry; 4b, Ilex barillensis Berry, n. sp.; 5, Sabalites grayanus (Lesquereux) Berry (?). 
3 
Leaves of fan palms are the most abundant fossils in the basal tuffs of the Barilla Mountains. The material is fragmentary, and as it represents both large and small leaves more than one species may be represented. It has seemed best, however, to consider all the specimens collected as representing different-sized leaves of a single species, as no differential characters other than those of size can be distinguished.

It is with considerable hesitation that I identify these remains as belonging to this species, and possibly instead of representing Sabalites grayanus they should be referred to Sabal ungeri (Lesquereux) Knowlton, which is exceedingly common in the Raton formation of Colorado and New Mexico and possibly occurs elsewhere in the Eocene of the western United States. There is also the further possibility, alluded to by Knowlton, that the two may represent a single species, and in any event the convergence of characters is marked and they are at least closely related. The following description of Sabalites grayanus is quoted from my account of the Wilcox occurrence:

Leaves of large size but mostly fragmentary. Petiole long and stout, unarmed, enlarged at the base of the leaf, and tapering into an extended and gradually narrowed acumen, which is not visible on the upper surface of the leaf, where the petiole is broadly rounded and a short and inconspicuous ligule is developed. From the manner of preservation and attitude of the rays on some of the specimens it is inferred that the acumen was recurved, as it is in the existing Sabal palmetto (Walter) Roemer and Schultes. Rays very numerous, about 100 in number, a few reduced basal ones on each side free, the remainder united for a variable distance above the base. Their dimensions and the relative thickness of the venation are variable features dependent on the size of the leaves. The largest specimens seen have thick carinate stout-veined rays, 5 centimeters in maximum width. They increase in size from the base of the leaf upward, and individually they are narrow at their point of attachment, widening medially and becoming gradually narrowed into long acuminate tips. Venation characters variable, largely dependent on the size of the leaves and the condition of preservation of the epidermis in the fossil specimens. In well-preserved material there are four or five relatively thin intermediate veins. Between each pair of veins there are six to eight fine veinlets, which are not visible except in well-preserved specimens.

Sabalites grayanus is a somewhat protean species which was described by Lesquereux from the Wilcox clays ("Eolignitic") of Lafayette County, Miss. None of Lesquereux's type material appears to be extant at the present time, but it seems probable that it came from a locality near Oxford. Within the next ten years after the publication of his original description of this species Lesquereux identified it from a large number of localities in Colorado, Wyoming, and Vancouver Island. Nearly all of this material is now in the United States National Museum and in my judgment does not represent this species. Knowlton ${ }^{1}$ has recorded five species of Sabal-like palms from the Raton formation of southeastern Colorado and northeastern New Mexico. Palm leaves are the most abundant fossils in that formation, and the wealth of this somewhat intractable material (so far as generic and specific differentiation is concerned) affords abundant testimony regarding the climatic conditions and the abundance and variety of the palms in the early Eocene history of the Rocky Mountain region.

\section{Genus GEONOMITES Visiani.}

Geonomites visianii Berry, n. sp.

Plate II.

Leaves of medium size, orate in general outline, becoming cleft distad at maturity. Length (estimated) about 75 centimeters; maximum width (estimated) about 40 centimeters. Rachis very stout, as much as 1 centimeter in diameter in the preserved material, very prominent on the under surface of the leaf, where it is semicircular in section, not keeled; flat or channeled on the upper surface. Laminae inserted on the lateral margins of the upper surface of the rachis, consisting of 75 to 100 undifferentiated rays on each side, which are united for all or a greater part of the distance to the margin. The rays are but slightly if at all plaited and do not contract proximad. They diverge from the rachis at angles averaging about $30^{\circ}$ and curve upward slightly and regularly as they proceed toward the margin. They are 6 to 8 millimeters in width, with a thin principal vein, and 10 to 12 thin parallel veins on either side of the principal vein. (See fig. 1.)

The texture of these leaves appears to have been coriaceous, for although their substance has mostly disappeared during fossilization they

1 Knowlton, F. H., U. S. Geol. Survey Prof. Paper 101, pp. 288-291, 1918. 


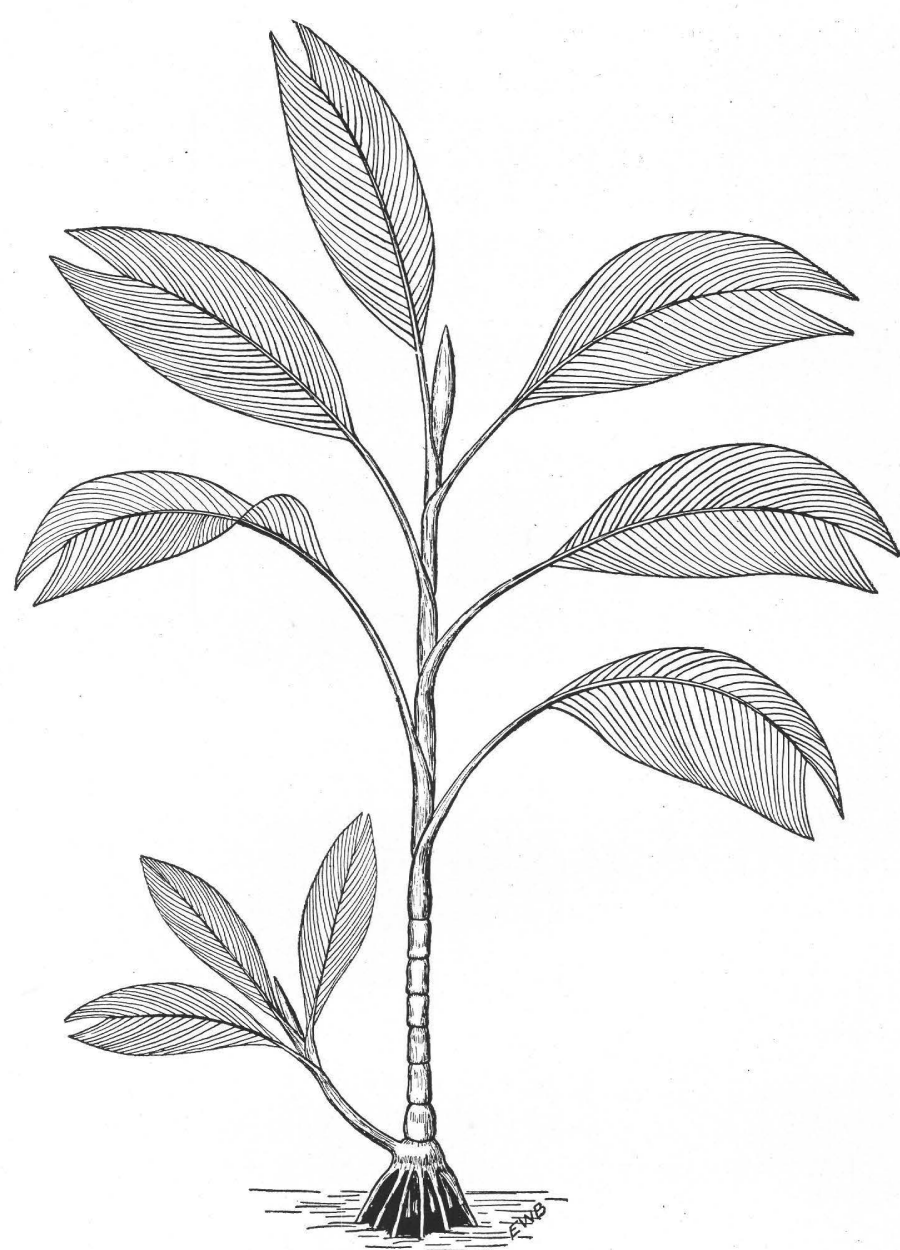

Figure 1.-Restoration of Geonomities visianii Berry, n. sp. One-fifteenth natural size. representatives of the tribe Geonomeae. This tribe includes at least ten genera, three of which, all monotypic, are natives of western Africa. The remaining genera, containing 98 per cent of the known species, are widely distributed in tropical and subtropical America. Most of these seven genera are small, containing from one to five existing species. The only large genus of the tribe is Geonoma, which comprises between 80 and 100 existing species that extend from the Antilles and southern Mexico through Central America, along the eastern base of the Andes to Bolivia, and along the east coast of South America to Rio de Janeiro. Their center of distribution at the present time is in the basin of the Amazon. They are prevailingly small stemless or short-stemmed palms and are undoubtedly of American origin. The fossil representatives of the Geonomeae comprise several Eocene and Oligocene forms of both North America and Europe which have been referred to the genus Manicaria of Gaertner; three forms referred to Geonoma; and six forms referred to Geonomites. The earliest known species of both Geonoma and Geono-

lie almost perfectly flat in the tuffs, whereas all $\mid$ mites occur in the early Eocene (Raton and the other associated plant remains are more or Denver formations) in Colorado and New less bent or contorted. It is of course possible Mexico. The species Geonomites schimperi, that the tuffs may represent both water-laid from Yellowstone Park, has been referred to and wind-blown volcanic ash, a conclusion that the Laramie formation, but the age of the outappears probable in regard to the matrix of crop is uncertain and is probably Eocene. most of the dicotyledonous leaves found at this This species has also been recorded from the locality, which is slightly different in appear- Tertiary of Contra Costa, Calif. Geonomites ance from the matrix of the Geonomites and is suggestive of certain similar leaf-bearing clays of the Fayette and Catahoula sandstones of eastern Texas that are known to have had such an origin, at least in part. On the other hand, no lithologic differences are observable between the Geonomites matrix and that inclosing the bent remains of Sabalites.

The genus Geonomites, which receives its name from its resemblance to the existing genus Geonoma of Willdenow, is more properly considered to represent the undifferentiated ancestry or the generically indistinguishable fossil goldianus Lesquereux, a Denver species, has been reported from the Eocene of Wyoming. A species has been reported from the supposed Upper Cretaceous along the Rio Grande in Texas, but I have reexamined the material, which proves to be that of a distorted fan palm of the Sabalites type, in no wise related to Geonomites. The earliest known European form, the type of the genus, comes from the lower Lutetian of Italy. A second species, referred to Geonoma by its describer, comes from the Oligocene of Italy, and a third, likewise referred to Geonoma, comes from the lower Miocene of Switzerland. 
Although the geologic record is thus incomplete, it would seem to indicate a tropical origin for the tribe, possibly in late Upper Cretaceous time, a spread northward far into western North America during the early Eocene, and an invasion of southern Europe, possibly extending to tropical Africa, during the middle Eocene or slightly later. An opinion as to whether the tribe migrated to the Eastern Hemisphere across the Tropics or in higher latitudes is not warranted in the present state of our knowledge.

Geonomites has not yet been found in the extensive Eocene floras from the shores of the Mississippi embayment which I have described. The fact that the bulk of these plants have been collected from the old eastern shores of this Eocene gulf may or may not be significant. The absence of Geonomites in the Wilcox flora rather lends support to the view that the basal tuffs of the Barilla Mountains are somewhat older than the Wilcox-that is, they are of Midway age. I also conclude that the Raton and Denver formations along the present Rocky Mountain Front Range are likewise older than the Wilcox.

\section{Class DICOTYLEDONAE. Order JUGLANDALES. \\ Family JUGLANDACEAE. \\ Genus JUGLaNs Linné. \\ Juglans rugosa Lesquereux.}

Juglans rugosa Lesquereux, Am. Jour. Sci., vol. 45, p. 206, 1868; The Tertiary flora: U. S. Geol. Survey Terr. Rept., vol. 7, p. 286, pl. 83, figs. 4, 5; pl. 84, figs. 1-9; pl. 85, figs. 1, 2, 1878. (Not Lesquereux, 1888, or Hollick, 1899.)

Knowlton, U. S. Geol. Survey Prof. Paper 101, p. 293, pl. 112, fig. 4, 1918.

This somewhat variable species had a wide range during the Eocene in western North America and has been recorded from Canada, Montana, Wyoming, Yellowstone Park, Colorado, California, Oregon, and New Mexico. It is distinctly a lower Eocene type and is a characteristic form in the floras of the Denver and Raton formations. It was recorded from the lower Eocene of the Mississippi embayment region by both Lesquereux and Hollick, but these occurrences do not represent this species, which so far as known did not exist in that region until later in the Eocene. The species is represented by over a dozen specimens, mostly fragmentary, in the basal tuffs of the Barilla Mountains. .

\section{Order RANALES. \\ Family ANONACEAE. \\ Genus ASIMINA Adanson.}

Asimina eocenica Lesquereux (?).

Asimina eocenica Lesquereux, U. S. Geol. and Geog. Survey Terr. Ann. Rept. for 1872, p. 387, 1873; The Tertiary flora, p. 251, pl. 43, figs. 5-8, 1878.

Berry, U. S. Geol. Survey Prof. Paper 91, p. 14, 1916.

Three or four not very perfect specimens in the basal tuffs of the Barilla Mountains are questionably referred to this species. It was described by Lesquereux in 1878 in the following terms:

Leaves very entire, lanceolate, equally gradually tapering downward to a short, thick petiole and upward to a point; nervation pinnate, camptodrome. I have seen a large number of specimens of these leaves, varying in size from 8 to 15 centimeters long and from $2 \frac{1}{2}$ to 4 centimeters broad in the middle, where they are widest, and there oblong, gradually narrowing upward and downward. The consistence of the leaves is somewhat thick but not coriaceous; the midrib thick, the lateral veins numerous, parallel, all under the same angle of divergence of $50^{\circ}$, slightly curved in traversing the lamina, generally simple or branching once toward the borders, which they follow in a series of bows, formed by anastomoses with veinlets or branches. The nervilles are distinctly marked, at least upon some well-preserved specimens like the one of figure 8 ; they are generally joined in the middle of the areas by oblique veinlets, forming large equilateral meshes, the ultimate areolation being indiscernible. These leaves differ especially from our $A$. triloba by their oblonglanceolate shape, those of the living species being generally enlarged upward and more distinctly oblong-obovate and proportionally broader. The nervation compared in both the small and the large leaves of the living species fully agrees with that of these fossil leaves, the lateral veins becoming closer and more distinctly marked in the small leaves, as it is in figure 5. It is the same with the tertiary intermediate nerves, which are scarcely, if ever, distinctly marked upon the small or middle-sized leaves of the papaw, while they appear, if not numerous, at least perfectly distinct, in the large ones. A fruit referable to this genus is described in the Eocene [Wilcox] flora of the Mississippi as Asimina leiocarpa Lesquereux.

The species Asimina eocenica is common in the Denver formation of Colorado and occurs also at Carbon and Black Buttes, Wyo. It is also present in the Midway (?) Eocene of Texas. It has been recorded by Knowlton from the Montana group, but this identification I regard as incorrect. It is probably present in the Raton formation, being not 
unlike leaves from the Raton which have been referred to the European Tertiary species Juglans acuminata Al. Braun. Possibly also some of the leaves that have been referred to Nectandra lancifolia (Lesquereux) Berry may represent this species of Asimina. ${ }^{1}$

\section{Order SAPINDALES. \\ Family ILICACEAE. \\ Genus ILEX Linnê. \\ Ilex barillensis Berry, n. sp. \\ Plate III, figure $4 \mathrm{~b}$.}

Sessile or subsessile, slightly inequilateral leaves of relatively small size, about 6 centimeters in length and 2.6 centimeters in maximum width at or below the middle; with a pointed tip, a broadly rounded abrupt base, a conspicuously toothed margin, and a subcoriaceous texture. The marginal teeth are large, remote, and irregularly spaced, unlike on the opposite margins; some approach a dentate form, others are serrate, and others salient-serrate. The midrib is stout, rather prominent, ourved. Secondaries fairly stout, about eight subopposite to alternate pairs; they diverge from the midrib at approximately regular intervals and are camptodrome, sending tertiary branches into the marginal teeth where those are present. Tertiaries form an open areolation tending to be quadrangular in appearance. (See fig. 2.)

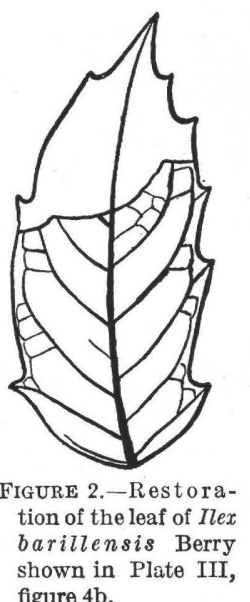

This species, which is obviously new, is unfortunately represented by a scanty amount of material. In general form it greatly resembles some of the existing western liveoaks, as for example Quercus agrifolia Née and Quercus chrysolepis Liebmann, or the so-called black oak, Quercus emoryi Torrey, of the mountain ranges of the arid Southwest. The venation, however, is unlike anything occurring in Quercus, in which the areolation is closer meshed and different in character and the secondaries taper more abruptly, are less regularly spaced or curved, and are cras-

1 Cf. Knowlton, F. H., U. S. Geol. Survey Prof. Pa per 101, pl. 90, fig. $1,1918$. pedodrome in the toothed-margin forms. On the other hand, the venation in both its gross and minute features is typical of the genus Mex, and the general form is not unlike that of numerous modern species of that genus, as for example the serrated forms of the oommon English holly or our own Ilex opaca Aiton. Moreover, the plants associated with the fossil species lend credence to the view that the habitat was somewhat similar to that required by our modern holly, namely, that it was a bottom-land or mesophytic species, rather than one of exposed, arid, or cool habitat. While Mex opaca ranges from Massachusetts to Florida it is rare in the Allegheny Mountains and finds its optimum habitat in the bottoms of southern Arkansas and eastern Texas.

\section{Order THYMELEALES.}

Family LAURACEAE.

\section{Genus OREODAPHNE Nees.}

Oreodaphne pseudoguianensis Berry.

Plate III, figures 1-3, 4a.

Oreodiphne pseudoguianensis Berry, U. S. Geol. Survey Prof. Paper 91, p. 305, pl. 81, figs. 3, 4, 1916.

This species and Sabalites grayanus are by far the most abundant forms in the basal tuffs of the Barilla Mountains. The Oreodaphne was described by me from the Wilcox Eocene of Louisiana and oontemporaneous beds in Tennessee in 1916 as follows:

Leaves narrowly elongate-lanceolate and falcate in general outline, the apex gradually attenuated and the base somewhat shorter, aruminate. Length ranges from 15 to 18 centemeters. Maximum width, in the lower half of the leaf, 1.7 to 2 centimeters. Margins entire, very faintly undulate. Leaf substance very thick. Texture decidedly coriaceous. Petiole long, stout, and curved, about 3 centimeters in length. Midrib stout, prominent on the lower surface of the leaf. Secondaries stout, prominent on the lower surface of the leaf; three or four coinmonly subopposite pairs of the same character, above which in the attenuated tip are numerous thin reduced pairs, diverging at wide angles. The basal pair are opposite and subbasal, diverging from the midrib at angles of about $20^{\circ}$, rather straight in their course and close to and parallel with the lower lateral margins. The succeeding two or three pairs, generally subopposite, arise at intervals of 1.5 to 2.5 centimeters. They diverge at slightly wider angles, about $30^{\circ}$, and are regularly curved and ascending, becoming parallel with the lateral margins, along which they ascend for a considerable distance, and are eventually camptodrome. The second- 
aries diverge at wider and wider angles and are more curved in the upper half of the leaf until in the tip they become very thin and diverge at angles of about $70^{\circ}$, running straight about halfway to the margin, where they turn abruptly upward to form wide arches to the adjacent superior secondaries. Tertiary venation largely immersed, consisting of transverse, slightly curved nervilles.

This species is one of the most distinctive fossil species of Lauraceae known, and as it is so much more abundant in the tuffs of the Barilla Mountains than at the type localities the foregoing description may be somewhat amplified, particularly as regards the limits of variation and the areolation. Thus the smallest leaves have a length of but 8 centimeters and a maximum width of but 8 millimeters, while the maximum width of the largest specimens is 2.25 centimeters. The areolation is fine meshed and the nervilles, both those at approximately right angles to the midrib and those forming wide angles with them, appear more prominent, giving the areolation a decidedly quadrangular appearance, although in reality the areolation is prevailingly polygonal. The appearance of these leaves is well shown in the accompanying illustrations, and they distinctly corroborate the comparisons made between the type and the existing Oreodaphne guianensis Aublet, of northern South America. In fact, but for the greater development of the lower secondaries in the fossil, the two are scarcely to be differentiated. 